\title{
Pembelajaran Campuran (Blended Learning)
}

Oleh: Janner Simarmata

Universitas Negeri Medan

Istilah Blended learning berasal dari bahasa inggris yaitu dari dua suku kata blended dan learning. Blended adalah campuran, kombinasi yang baik, sedangkan learning adalah pembelajaran, sehingga bila definisikan bahwa Blended learning adalah suatu metode pembelajaran yang memadukan proses pembelajaran konvensional dengan materi online secara sistematis. Dengan demikian, blended learning mengandung makna model pembelajaran yang mengandung unsur pencampuran atau penggabungan antara satu model dengan model lainnya.

Berikut ini adalah beberapa definisi-definisi tentang blended learning:

Graham (2006) mendefinisikan blended learning sebagai "kombinasi dari dua model pendidikan yang berbeda, pembelajaran tradisional tatap muka (face to face learning) dan pembelajaran jarak jauh (distance learning )". Blended learning juga dapat didefinisikan sebagai pengintegrasian pembelajaran tatap muka dengan pembelajaran elektronik atau pembelajaran jarak jauh dengan menggunakan perbedaan teori-teori pembelajaran, metodologi dan teknik belajar di tempat yang sama dan mendukung pembelajaran dengan berbagai teknologi online selama proses pembelajaran di kelas dilakukan (Rossett 2002 ).

Suprabha, K. \& Subramonian, G. (2015:1) mengemukakan bahwa Blended learning melibatkan pergeseran dari interaksi kelas murni, gaya pengajaran kepada gaya yang lebih berpusat pada siswa. Sistem pendidikan saat ini menuntut pendidikan berpusat pada peserta didik dan blended learning adalah cara yang paling tepat.

Lingkungan Blended learning mengintegrasikan keuntungan dari metode e-learning dengan beberapa aspek dari metode tradisional, seperti interaksi tatap muka. Blended learning membawa kelas fisik tradisional dengan unsur pendidikan maya secara bersamaan (Finn \& Bucceri, 2004).

Sebagaimana Brown (2003) menyatakan bahwa blended learning mendukung semua manfaat dari e-learning termasuk pengurangan biaya, efisiensi waktu dan kenyamanan lokasi untuk peserta didik serta pemahaman pribadi dan memotivasi penyajian pembelajaran tatap muka. Telah banyak definisi lain dari blended learning yang diajukan dalam literatur, sederhananya menurut Singh \& Reed (2001) mendefinisikan bahwa blended learning sebagai program pembelajaran di mana lebih dari satu bentuk pengiriman yang digunakan dengan tujuan mengoptimalkan hasil belajar dan biaya pelaksanaan pembelajaran.

Blended learning dijelaskan oleh Thorne (2003) adalah sebagai "suatu cara untuk memenuhi tantangan yang menyesuaikan pembelajaran dan pengembangan untuk kebutuhan individu dengan mengintegrasikan kemajuan inovatif dan teknologi yang ditawarkan oleh pembelajaran online dengan interaksi dan partisipasi yang ditawarkan dalam pembelajaran tradisional". 
Blended learning yaitu menggabungkan berbagai kegiatan seperti pertemuan tatap muka, modul belajar berbasis Internet, dan komunitas belajar virtual (Link, \& Wagner, 2009). Nuruzzaman, A. (2016:126) mengatakan Blended learning menunjukkan berbagai kemungkinan yang disajikan dengan menggabungkan media digital dan internet dengan bentuk kelas yang mapan yang memerlukan kehadiran bersama secara fisik dari guru dan siswa. Blended learning menggambarkan kegiatan pembelajaran yang melibatkan kombinasi interaksi tatap muka yang sistematis dan teknologi antara siswa, guru dan sumber belajar seperti yang dijelaskan oleh Bliuca \& Ellisc (2007:234).

Graham (2006:5) merangkum tiga definisi blended learning sebagai (a) kombinasi media pengiriman pembelajaran, (b) kombinasi metode pembelajaran, dan (c) kombinasi pembelajaran tatap muka dan secara online. Osguthorpe \& Graham (2003:227) menggambarkan model blended sebagai "pedagogi yang berubah sesuai dengan kebutuhan unik dari peserta didik. Mereka yang menggunakan lingkungan blended learning mencoba untuk memaksimalkan manfaat dari kedua metode ini, baik tatap muka dan maupun secara online.

Dzakiria et.al, (2006:12) mengatakan sebuah materi yang memadukan secara online dan tatap muka, proporsi yang besar dari konten dikirimkan secara online, biasanya menggunakan diskusi online, dan memiliki beberapa pertemuan tatap muka.

Cheung \& Hew (2011:1319) menjelaskan blended learning adalah perpaduan pembelajaran tatap muka dengan pembelajaran online. Sementara Samarescu. N (2016:620) mengatakan bahwa Blended learning merupakan bentuk pembelajaran campuran yang menggabungkan pembelajaran tradisional dengan teknologi yang tersedia saat ini. Khan et al (2012:311) menyebutnya bahwa Blended learning diberi nama yang berbeda sepanjang tahun, seperti 1) hybrid instruction, 2) mediated learning, 3) technology enhanced instruction, 4) web enhanced instruction, dan 5) web assisted instruction. Saat ini, blended learning tampaknya menjadi istilah secara "de facto" yang mengacu pada lingkungan belajar campuran. Di sisi lain, blended learning dikritik karena campuran yang dimaksud terjadi tidak dalam pembelajaran, tetapi dalam pengajaran.

Zaeri. N (2013:34) mengatakan blended learning didasarkan pada berbagai kombinasi pembelajaran tatap muka, pembelajaran melalui Internet, dan pembelajaran yang didukung oleh teknologi lainnya yang bertujuan untuk menciptakan lingkungan belajar yang efisien. Hal ini juga mencakup unsur-unsur lain seperti teknologi dan media untuk pengiriman konten pembelajaran, kegiatan belajar kelompok dan individu, dan interaksi secara sinkron dan asinkron.

Senada dengan definisi di atas, Nair, T.S \& Bindu, R.L (2016:41) menyampaikan bahwa strategi blended learning adalah pendekatan terpadu untuk menggunakan berbagai sumber dan aktivitas dalam memberikan pengalaman belajar individual dan berpusat pada siswa.

Singh, H., \& Reed, C. (2001:2). Penggunaan frasa "Blended Learning" yang asli sering dikaitkan dengan hanya menghubungkan pelatihan kelas tradisional dengan aktivitas 
eLearning. Namun, istilah ini telah berkembang mencakup seperangkat "dimensi" strategi pembelajaran yang lebih kaya dan saat ini, program pembelajaran campuran (blended learning) dapat menggabungkan satu atau beberapa dimensi. Sementara Heinze, A. \&

Procter, C. T (2004:2) menjelaskan bahwa Blended learning adalah kombinasi efektif dari berbagai mode pengiriman, model pengajaran dan gaya belajar, definisi ini lebih komprehensif, menambahkan dimensi gaya belajar dan mengajar.

Lalima \& Dangwal, K.L (2017:131) menjelaskan bahwa Blended learning adalah konsep yang mencakup proses belajar mengajar yang menggabungkan pengajaran dan pengajaran tatap muka yang didukung oleh TIK. Blended learning menggabungkan instruksi langsung, instruksi tidak langsung, pengajaran kolaboratif,dan pembelajaran berbantuan komputer.

Blended learning sering dikaitkan dengan pembelajaran yang berorientasi pada siswa (student-oriented learning), dimana siswa memiliki tingkat kontrol yang berbeda atas proses belajar mereka sendiri. Blended Learning dapat berkontribusi pada otonomi siswa karena memungkinkan mereka memiliki kontrol lebih terhadap jalur belajar mereka dan otonomi ini harus mendorong siswa untuk bertanggungjawab atas proses mereka sendiri (Lust, Elen, \& Clarebout, 2013).

Dalam arti luas, blended learning dapat didefinisikan atau dikonseptualisasikan sebagai kombinasi dari beragam teknologi / media yang terintegrasi ke dalam kegiatan kelas tatap muka, seperti yang ditulis oleh Mayadas, A., \& Picciano, A. (2007:4).

Blended learning tujuannya adalah untuk membangun keseimbangan antara pembelajaran tatap muka dan online. Keseimbangan yang dimaksud dapat berubah dari satu materi ke materi yang lainnya. Karena fitur dasar dari beberapa pelajaran bahwa pembelajaran tatap muka yang paling banyak digunakan, sementara pada pelajaran lain pembelajaran online juga lebih banyak digunakan.

\section{Referensi:}

Bliuca A.M., Goodyearb P. \& Ellisc R. A. (2007). Research Focus and Methodological Choices in Studies into Students' Experiences of Blended Learning in Higher Education. The Internet and Higher Education, Volume 10, Issue 4, 231- 244.

Brown, R. (2003). Blending learning: Rich experiences from a rich picture. Training and Development in Australia, 30 (3), 14-17.

Cheung, WS. \& Hew, KF. (2011). Design and Evaluation of two Blended Learning Approaches: Lessons learned. Australasian Journal of Educational Technology, 2011, v. 27 n. 8, p. 1319-1337.

Dzakiria, H., Mustafa C.S. \& Bakar, H.A. (2006). Moving Forward with Blended Learning (BL) as a Pedagogical Alternative to Traditional Classroom Learning, Malaysian 
Online Journal of Instructional Technology(MOJIT), Vol. 3, No.1, pp 11-18 April 2006 ISSN 1823.

Finch, C. R. \& Crunkilton, J. R. (1999). Curriculum development in vocational and technical education: planning, content and implementation. Boston: Allyn and Bacon, Inc.

Graham, C. R. (2006). Blended learning systems: Definition, current trends, and future directions. In C. Bonk \& C. Graham (Eds.), The Handbook of Blended Learning:Global Perspectives, Local Designs (Vol. San Francisco, CA, pp. 3-21).

Heinze, A. \& Procter, CT. (2004). Reflections on the use of Blended Learning, in: Education in a Changing Environment, 13-14 September 2004, University of Salford, UK.

Khan. AI, Noor-ul-Qayyum, Shaik. MS, Ali. AM. \& Bebi. CV. (2012). Study of Blended Learning Process in Education Context, I.J. Modern Education and Computer Science, 2012, 9, 23-29 Published Online September 2012 in MECS (http://www.mecs-press.org/) DOI: 10.5815/ijmecs.2012.09.03

Lalima \& Dangwal, K.L. (2017). Blended Learning: An Innovative Approach. Universal Journal of Educational Research 5(1): 129-136, 2017. DOI: 10.13189/ujer.2017.050116

Link, L., Wagner, D.(2009). "Computer' Mediated Communication in Virtual Learning Communities in Zaphiris", P. \& Ang, C.S. (eds.) (2009). Human Computer Interaction: Concepts, Methodologies, Tools and Applications.Information Science Reference, Hershey, New York, 316'322.

Lust, G., Vandewaetere, M., Ceulemans, E., Elen, J., \& Clarebout, G. (2011). Tool-use in a blended undergraduate course: In Search of user profiles. Computers \& Education, 57(3), 2135-2144.

Mayadas, A., \& Picciano, A. (2007). Blended Learning and Localness: The Means and The End. Journal of Asynchronous Learning Networks 11(1): 3-7.

Nair, T.S \& Bindu, R.L (2016). Effect Of Blended Learning Strategy on Achievement in Biology and Social and Environmental Attitude of Students at Secondary Level. imanager 's Journal on School Educational Technology, Vol. 11 No. 41.

Nuruzzaman, A. (2016). The Pedagogy of Blended Learning: A Brief Review. IRA International Journal of Education and Multidisciplinary Studies (ISSN 2455-2526), 4(1). doi: http://dx.doi.org/10.21013/jems.v4.n1.p14

Osguthorpe RT. \& Graham CR (2003). Blended Learning Environments: Definitions and Directions. Q. Rev. Distance Educ., 4(3): 227-234, ISSN-1528-3518.

Samarescu, N. (2016). The Teacher's Role in Blended Learning and Teaching, The 12th International Scientific Conference eLearning and Software for Education Bucharest, April 21-22, 2016 10.12753/2066-026X-16-270.

Singh, H. \& Reed, C. (2001). A white paper: Achieving success with blended learning. Centra software, 1, 1-11. 
Suprabha, K. \& Subramonian, G. (2015). Blended Learning Approach For Enhancing Students Learning Experiences In A Knowledge Society. i-manager 's Journal of Educational Technology Vol. 11 No. 4.

Thorne, K. (2003). Blended learning: How to integrate online and traditional learning , London: Kogan Page.

Zaeri. N. (2013). Blended Learning System Performance Evaluation, International Journal of Computer Applications (0975 - 8887) Volume 76- No.4, August 2013. 